\title{
De gjorde musikken til deres identitet
}

af seniorforsker, dr.phil. Jens Henrik Koudal,

Dansk Folkemindesamling, Det Kongelige Bibliotek

C6 7 ortæl hvilken musik, du holder af, $\mathrm{F}$ og jeg skal sige dig, hvem du er", hævder en kendt talemåde. Det er sat på spidsen, men noget er der om det. Denne artikel belyser, hvordan en landmandsfamilie gennem to generationer havde musik som en meget væsentlig del af sin identitet. Den bygger på gårdens store privatarkiv, der rummer personlige dagbøger, erindringer, breve, skønlitterære forsøg, slægts- og lokalhistorie, familiefotos og musik. Papirerne blev skænket til Dansk Folkemindesamling i 2011. Arkivet har siden været genstand for et forskningsprojekt, ${ }^{1}$ og det er blandt andet blevet formidlet gennem en udstilling i Dronningesals-montrene på Det Kongelige Bibliotek i sommeren 2014.

Gården Torpelund ligger $13 \mathrm{~km} ø s t$ for Kalundborg, ved Saltbæk Vig, i et hjørne af Sjælland, hvor kragerne vender. Denne landbrugsbedrift blev fra 1865 til

Lufffoto af Torpelund 1937. Man kan ane et treflojet anlag omkring en gairdsplads. Bagerst i midten ses stuehuset fra 1892. Til venstre for gärdspladsen ligger svine-, heste- og kostalde og til hojre, delvis skjult bag traer, er der lade, molleri, maskinhus, honsehus m.m. En køkkenhave skimtes bagerst til hojre, mens resten af bevoksningen udgor parken, der bl.a. rummer en på billedet ikke synlig dam med en lille ø. (Sylvest Jensen lufffoto, Kort- og billedsamlingen, Det Kongelige Bibliotek).

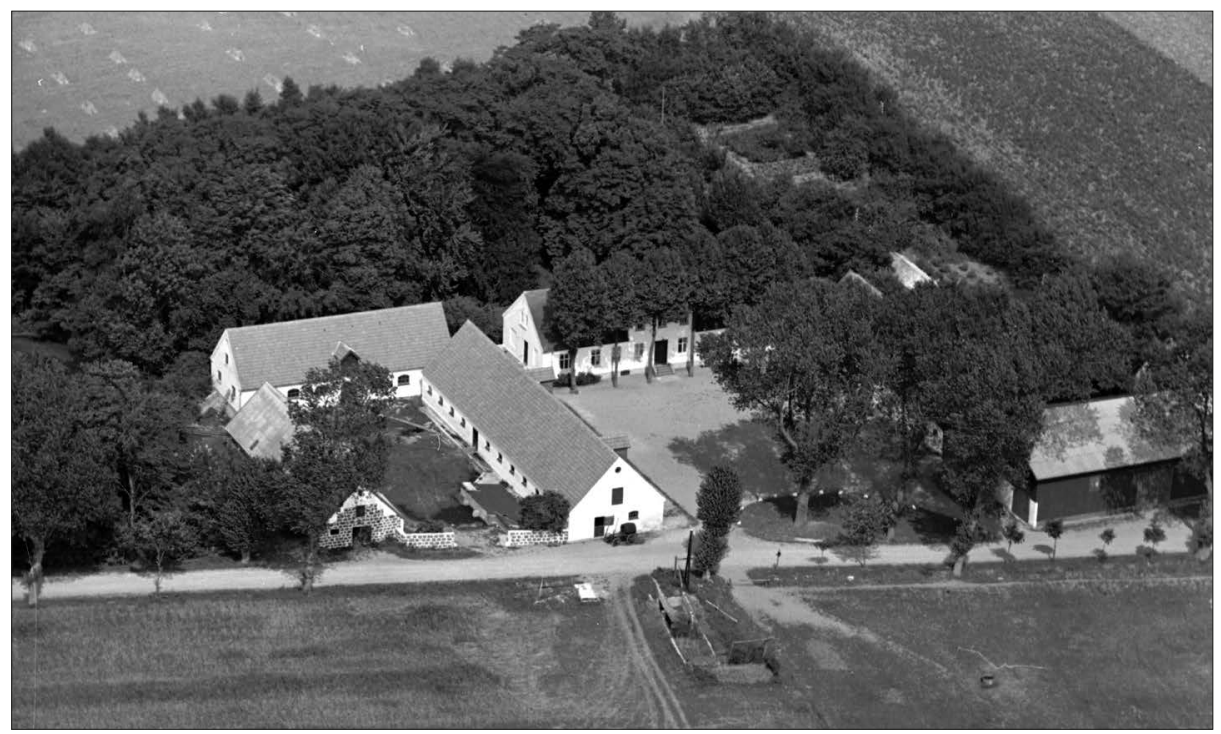




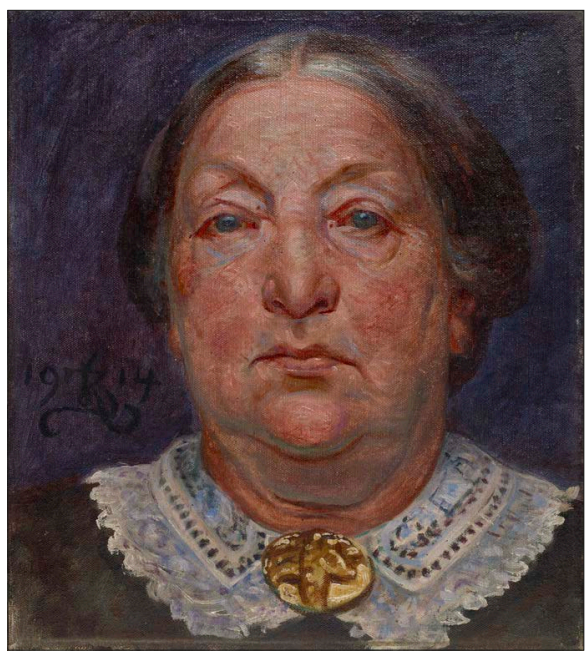

1968 ejet og drevet af to generationer af slægten Olsen. I hovedparten af perioden var den et samlingssted for musikudøvelse af privat karakter. En søn fra gården, Christian Olsen, kaldte da også sin familie for "en musikfamilie". Man opfattede sig som en særlig musikslægt. Det var selvbevidste folk. For eksempel har Kristian Zahrtman på bestilling i 1914 malet et portræt af enkefru Johanne Olsen, som dengang ejede gården.

Olsen-slægten var steget socialt fra at have været husmænd og fæstebønder i Nordvestsjælland i 1700-tallet til en proprietærlignende status på Torpelund $\mathrm{i}$ det 20. århundrede. Slægtens første generation på gården, Johanne (1844-1938) og Jens Olsen (1835-1901), arbejdede målbevidst på at effektivisere og udbygge produktionen for at ernære familien og oparbejde et $ø$ konomisk overskud. De bankede en gammeldags bondegård op til at blive det veldrevne fundament for et liv med kulturelle ambitioner. Disse viste sig blandt andet i anlæggelsen af en park, anskaffelsen af et klaver og i opførelsen af
Enkefru Johanne Olsen, der da ejede Torpelund, 1914. Kristian Zahrtmanns maleri blev bestilt af Christian Olsen som en gave til moderens 70 ärs fodselsdag. Trods Christians gode hensigter brod familien sig ikke om billedet, fordi man ikke syntes, det lignede modellen godt nok. Maleriet lå derfor i de folgende airtier gemt hen i en kommodeskuffe. (Dansk Folkemindesamlings billedarkiv).

et nyt, grundmuret stuehus. De to generationer på Torpelund opbyggede desuden en personkreds, der forenede selskabelighed og musik. Heri indgik fremtrædende musikere og andre kunstnere.

Fire af de seks børn, der voksede op på Torpelund, plus en håndfuld af deres fætre og kusiner, blev uddannet professionelt som musikere. Den nævnte Christian Olsen (1881-1968) fungerede som musiklærer og var på gården en slags familiær medhjælp. Han skabte sig desuden en rolle som familiens stemme udadtil gennem sin omfattende brevskrivning, sin bog om slægtens folkeminder, sine lokalhistoriske artikler og sine udgivelser af gamle dansemelodier fra Nordvestsjælland. Han havde i årene 1921-61 et fagligt samarbejde med Dansk Folkemindesamling. Den nye donation af hans privatarkiv til Det Kongelige Bibliotek afslører, at han desuden har skrevet dagbøger: Ikke mindre end 10.000 sider mellem 1915 og 1965. Amatørfotograf var han også. Håndskrifter og billeder fra Torpelund fylder i dag 10 meter på Dansk Folkemindesamlings hylder i Det Kongelige Bibliotek.

Jens Olsen og andre lokale musikanter Gårdejer Jens Olsen havde i sin ungdom fungeret som halvprofessionel dansemu- 
Portrat afJens Olsen o. 1855. Billedet er fra den periode, hvor han fungerede som musiker ved fester, baller og markeder i Nordvestsjalland. (Dansk Folkemindesamlings billedarkiv).

siker i Nordvestsjælland. Som oftest i et lille orkester med en bror og deres far: gårdmand, kroholder og sognefoged Anders Olsen i Jyderup. Efter erhvervelsen af Torpelund i 1865 ophørte Jens Olsen med at spille ude mod betaling. Han $ø$ nskede dog at videreføre sit violinspil. I første omgang lærte Jens døtrene at akkompagnere til egnens gamle danse. Efterhånden som

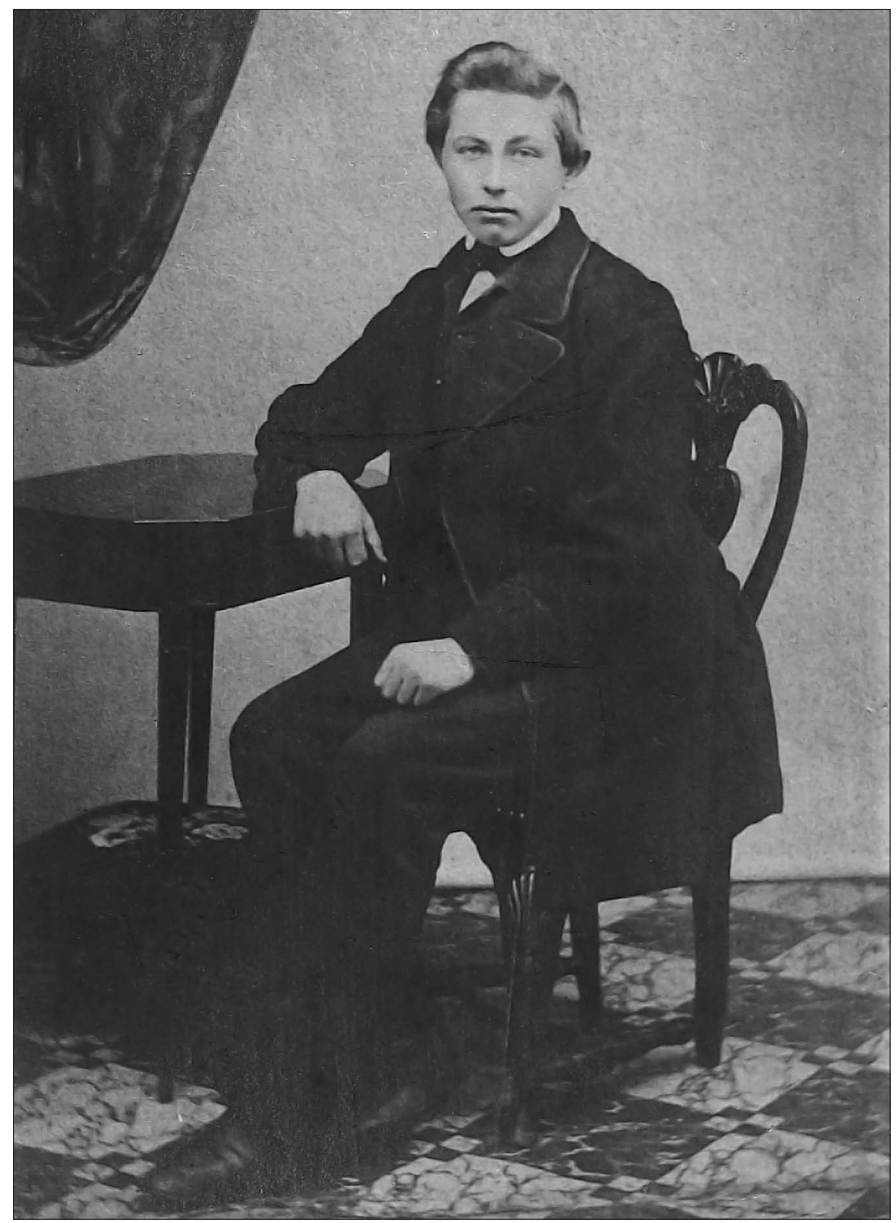

pigerne voksede op og blev bedre på klaveret, begyndte Jens at spille sonater med dem. I 1880'erne og 90'erne spillede Jens Olsen desuden flittigt sammen med damerne på egnens større gårde samt med diverse venner, herunder lokale dansemusikere. Også børnenes ungdomsvenner fra København blev medspillere, da fire af Torpelund-børnene efter 1889 drog til Hovedstaden for at uddanne sig som musikere.

Repertoiret på Torpelund var gamle danse og klassisk-romantisk kammermu- sik. "Gamle danse" var folkelige melodier fra 1700- og 1800-tallet med navne som menuet, kehraus, engelskdans, reel, vals, hamborger, polka, mazurka og galop. Det var netop disse dansemelodier, Christian Olsen møjsommeligt samlede og udgav. Denne musik havde en særlig status, for den repræsenterede en slægtstradition gennem fire generationer i Jens Olsens fædrene slægt. Dansene blev oftest brugt som lyttemusik på Torpelund. Endnu i mellemkrigstiden blev der dog også danset til dem ved fester. Dansemusikken 


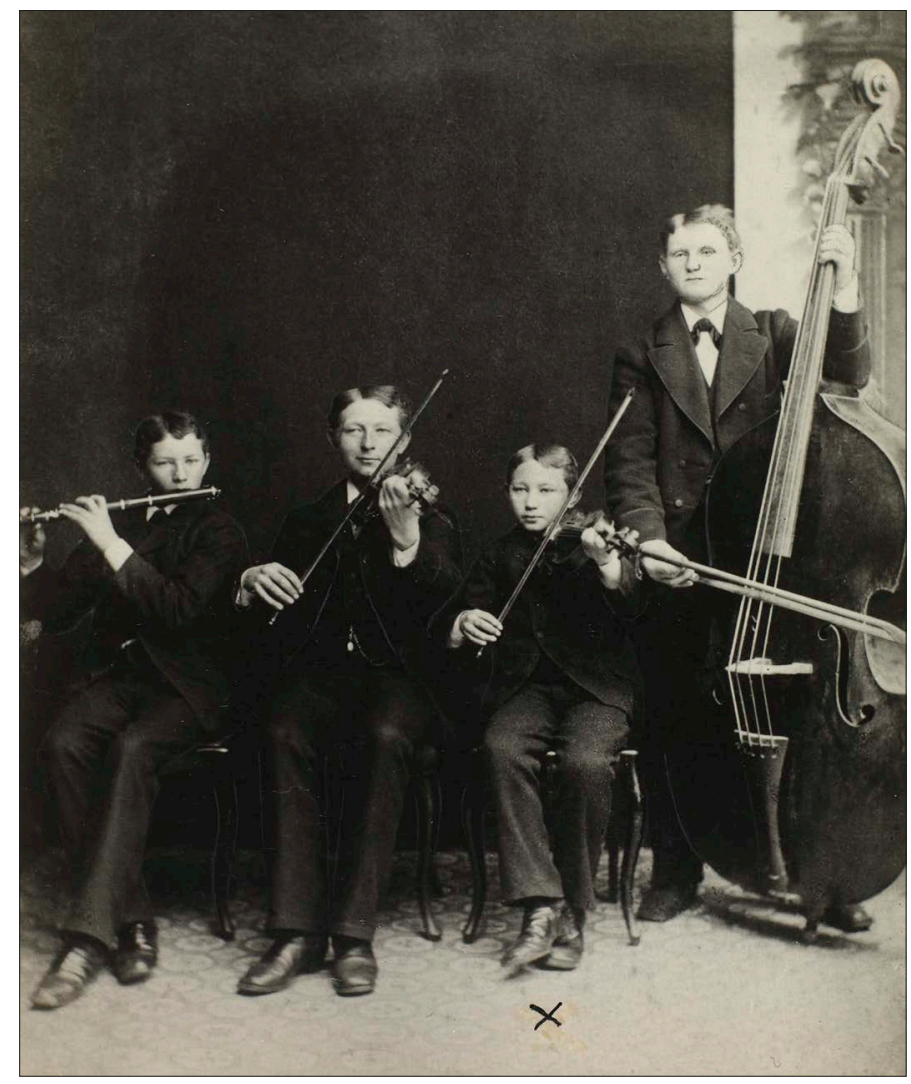

var uundværlig, men det var den klassiske musik, der fyldte mest på Torpelund.

\section{"Vor kreds" - Torpelund}

som musikalsk samlingssted

Den musikdyrkende kreds på Torpelund var de mennesker, der i gentagne tilfælde deltog i selskabelighed med musik på gården. Centralt i "vor kreds", som familien kaldte dem, stod folk fra familie og slægt samt gode venner fra egnens mellemstore og større landbrugsbedrifter. Forretningsforbindelser kunne også være repræsenteret. Andre deltagere var som sagt søskendeflokkens ungdomsvenner fra København. Desuden kunne der deltage indbudte musikere, malere, forfattere og historisk interesserede. Blandt de kendte personer, der kom på Torpelund mellem Første Verdenskrig og 1960'erne, var musikerne Frederik Marke, Kristian Sandby og Peder Møller, komponisten Louis Glass (der fremførte sine symfonier firehændigt på klaver med sin hustru), den norske dirigent J.L. Mowinckel samt sangerinderne Nora Elé og Lise Schlegel. Blandt forfatterne var Thit Jensen, Thorkild Gravlund, Else Moltke og Erik Aalbæk Jensen. Af malere kan nævnes Ove Rützou, Sigurd Swane, Mølmark Hansen og Harald Moltke. Hver havde sin særlige relation til Olsen-familien. 
Til venstre: Spillemandskvartet af bondesonnen Frederik Marke (nr. to fra hojre) og hans tre brodre omkring 1880. Man spiller tverflojte, to violiner og kontrabas. Frederik Marke blev senere kongelig kapelmusiker og giftede sig med Katrine Olsen fra Torpelund. (Museum Vestsjelland, Kalundborg Museum).

Til hojre: Peder Moller sendte i 1897 dette billede af sig selv som en julehilsen til familien på Torpelund. (Dansk Folkemindesamlings billedarkiv).

Kongelig kapelmusiker Frederik Marke og Ove Rützou var f.eks. gift med hver sin datter fra gården, henholdsvis Katrine og Christiane.

Peder Møller var Danmarks betydeligste violinist i mellemkrigstiden. Det var ham, Carl Nielsen skrev sin violinkoncert til. Omkring 1890 traf Møller Katrine og Christiane fra Torpelund, mens de alle tre boede og uddannede sig i København, og han blev også ven med deres tidligt afdøde bror, musikeren Hans Olsen. Peder Møller boede i mellemkrigstiden i "Møllers værelse" på Torpelund med sin familie i alle større ferier. Han underskrev sig i gæstebogen "søn

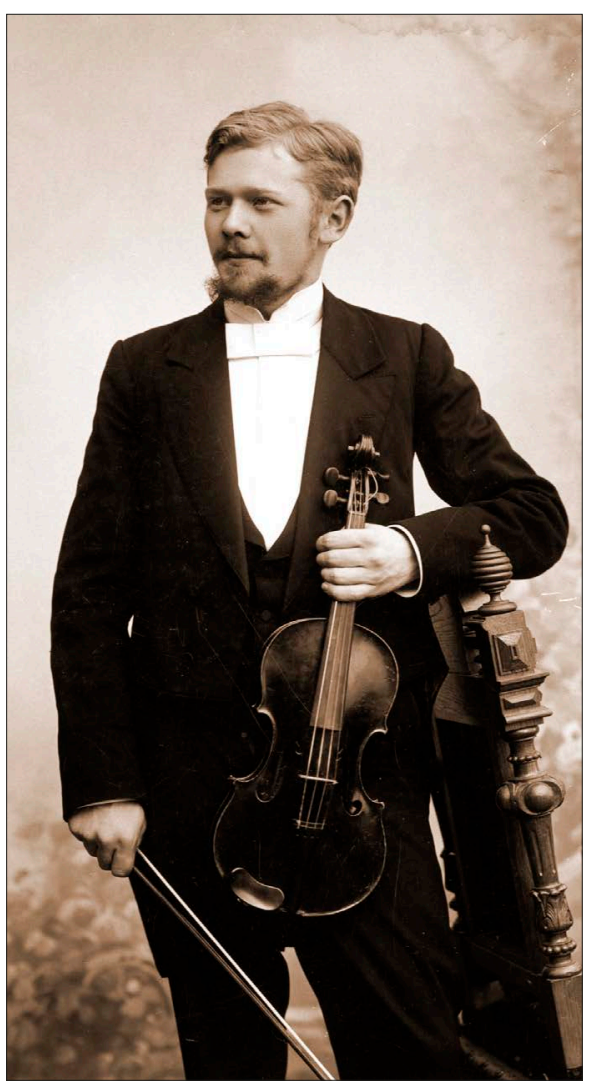

af huset". Som regel, når Møller skulle opføre Nielsens violinkoncert ved en koncert, kom han til Torpelund og indstuderede den med pianisten Christiane Rützou. Det foregik i dagligstuen, hvor klaveret stod. Man afsluttede selvfølgelig prøvearbejdet med at spille den hundesvære koncert for indbudte tilhørere fra "vor kreds".

Vi skal se et eksempel på, hvordan det kunne gå for sig, når man musicerede. I dette tilfælde vidner et notat af Christian Olsen om de musikoplevelser, Møller gav ham ved familiesammenkomster på Torpelund, som det for eksempel skete i julen 1916: 
“3die juledag 1916 hentede vi på stationen min fætter, [kongelig kapelmusiker] Kristian Sandby, violinvirtuosen Peder Møller, fru Møller og deres to børn Lise og Svend. Hen på eftermiddagen kom komtesse Lilli (Cornelia) Lerche fra "Sølyst" [i Jyderup] og hendes veninde fru Ingeborg. Ud på aftenen, efter at vi havde spist, var der een, der bad Peder Møller spille et eller andet og da han aldrig følte sig træt, eller var kostbar, foreslog han min søster, Christiane, at akkompagnere ham i Max Bruchs $G$ mol koncert. Det ville hun gerne og lidt efter spillede han den dejlige koncert med så skøn en tone og på en sådan måde, at man ligesom blev rykket bort fra jorden, bort til en vidunderlig skøn verden som man ikke sådan til hverdag kan færdes i."

Musikken på Torpelund blev spillet sammen med gæster og for gæster. Ofte var det lokale fætre og kusiner, der spillede. Andre gange trådte besøgende professionelle musikere til, beslægtede eller ej. Der var altid middag eller kaffebord i tilknytning til musikken. Amatører og professionelle musikere respekterede gensidigt hinanden. Når begge parter var til stede, havde de professionelle dog førsteret til at optræde. Repertoiret var især musik for små besætninger af Haydn, Mozart, Beethoven, Kuhlau, Weber, Schubert, Schumann, Chopin, Mendelssohn, Dvorak, Bizet, Bruch, Brahms, N.W. Gade, Liszt, Saint-Saens, Tjajkovskij, Grieg og Johan Svendsen. Man spillede meget lidt musik fra efter 1890, og da gerne komponister, der skrev i en stemningsfyldt, senromantisk stil som Louis Glass, Lange Müller og fætteren Herman Sandby. Den stilistisk mest moderne komponist, kredsen spillede, var Carl Nielsen.

\section{Christian Olsens indsamling og publikationer}

Christian Olsen var stolt af sin slægt og ønskede at kommunikere Torpelund-miljøets særpræg og de værdier, han hyldede, til offentligheden.

Christian Olsen var i 1921 i færd med at udgive den bog, han er mest kendt for, Fra Nordvestsjelland. Slagtsminder og Folkeminder (1923). I den forbindelse søgte han hos Dansk Folkemindesamling råd om udvælgelse og publicering af sang- og dansemelodier. Fra midten af 1920'erne blev han desuden optegner af folkeminder fra sin hjemegn til samlingen i København. I 1951 fik Christian Olsen for sit

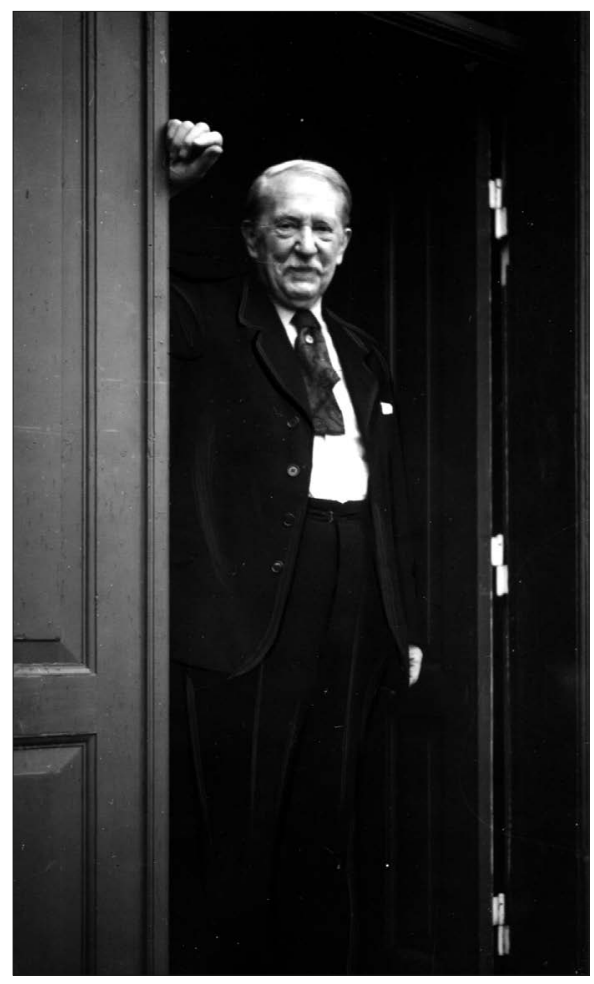

Christian Olsen i hoveddøren på Torpelund 1954. (Dansk Folkemindesamlings billedarkiv). 
indsamlingsarbejde tilkendt en mindre, livsvarig ydelse fra Undervisningsministeriet. Det fik ham til at donere sin håndskrevne samling af gammel dansemusik samt diverse personalhistorisk og lokalhistorisk stof til Dansk Folkemindesamling.

Olsens andet hovedværk er Gamle Danse fra Nordvestsjalland, der udkom i tre bind fra 1923 til 1928. Udgaven består af 227 dansemelodier, der er forsynet med klaverudsættelse af hans søster, pianisten Christiane Rützou. Udgivelsen rummer også en kulturhistorisk skildring af egnens dans og musik i perioden 1750-1900. Christian Olsen ønskede med publikationen at skabe en ny, levende gårdmandsmusik. Han ville ikke blot bevare, men også genindføre de gamle dansearter. Vel at mærke omskabt til karakterstykker for klaver, hvis formål var at fortrænge nyere populærmusik i det danske folk. Christian Olsen var en energisk modstander af ragtime, jazz og nyere slagermusik. Klaverudgaven med de gamle nordvestsjællandske danse var således led i en konservativ kulturkamp.

Man kan frit omskrive ideen i Gamle Danse fra Nordvestsjalland til 'bøndernes væsen belyst gennem deres dansemelodier'. Christiane Rützou overførte med stor fantasi spillepraksis fra landsbymusikanternes dansemusik til sine klaverudsættelser. Christian Olsen og Christiane Rützou ønskede at viderebringe deres slægts gamle danse til eftertiden som en konservativ kulturværdi, der skulle leve hos landbefolkningen i fremtiden. Klaverudsættelsen signalerede, at målgruppen primært var gårdmandsgruppen og højere sociale lag. Foruden bøgerne udgav Olsen som nævnt en række lokal- og personalhistoriske artikler samt en enkelt novelle i månedsskriftet Tilskueren.

\section{Musikkens betydning}

Man kan undre sig over, hvilken betydning dette stort set ukendte musikliv har haft for menneskene på en landbrugsbedrift.

Konservatismen i musikdyrkelsen havde sin rod i familiens opfattelse af Olsen-slægtens historiske betydning. Man bekræftede ofte for hinanden, at man var ud af en gammel musiker- og gårdmandsslægt. Christian Olsen mente endda, at det var en af de mest musikalske slægter i Nordvestsjælland, der samtidig var den mest musikalske del af Danmark uden for København. Jens Olsens Torpelund og hans faders gård, Skovgård i Jyderup, havde gennem musikdyrkelsen været " $m e$ lodiopsamlingssteder" for egnens danse. Jens Olsens musikalske slægtsarv i form af dansemusik blev på denne måde betragtet som en hel egns arv.

"Familiefortællingen" rummede flere lag. Politisk hyldede man endnu i mellemkrigstiden den gamle verdens patriarkalske værdier a la det gamle Højre. Man vedkendte sig at være "bønder", men bønder med kultur. Det var Christian Olsens store skræk, at "en dag ville vi alle gå ens klædt, og konformiteten ville komme over os og udslette alt særpræg". Inden for familiefortællingens ramme fungerede musik - både gammel dansemusik og kammermusik - som et udtryk for slægtsfølelse og en markør af årets og livets fester. I musiceringen bevarede og genskabte familiekredsen en forestillet gammel, autentisk verden. At spille og synge blev opfattet som en bondeslægts familietradition, der gik tilbage til 1700-tallet.

Musikkulturen var privat, for den dyrkede hjemmet og familiekredsen på en måde, der var usynlig for andre. Det 


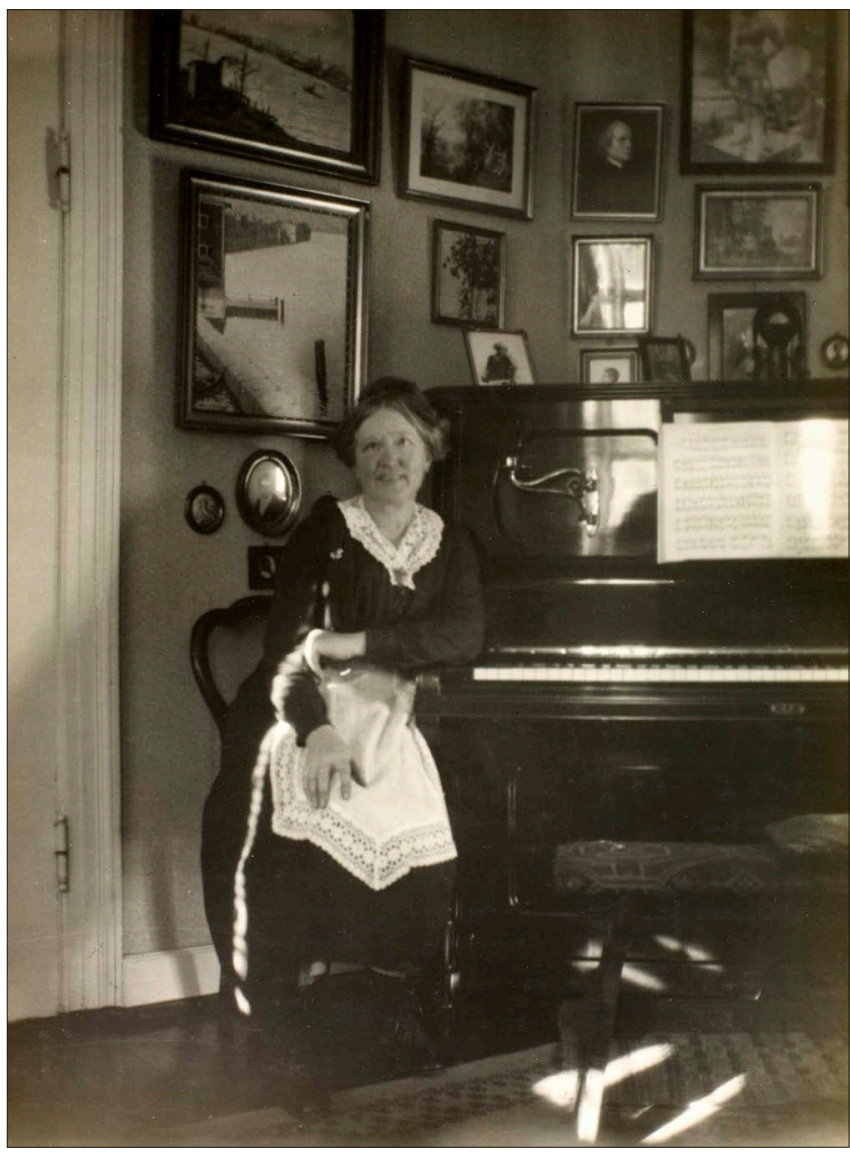

Christiane Rützou ved klaveret $i$ dagligstuen $p a ̊$ Torpelund 1923. (Dansk Folkemindesamlings billedarkiv).

var utænkeligt, at Christian Olsen og Christiane Rützou skulle spille offentligt til møder, baller eller folkedans. Man dyrkede gennem musikken selskabelighed og personlig tilegnelse af klassiske musikværker. Skridtet videre til selv at komponere kaldte Christiane Rützou "det privateste af det private". Hun havde komponeret mere end et dusin (trykte såel som utrykte) sange og små klaverstykker, som også af og til blev fremført.

Musikkulturen var endelig eksklusiv, for den skabte afstand til lavere socialgrupper og til folk med kulturelt og politisk moderne værdier (for eksempel radikale og socialistiske). Musicering på Torpelund var for de udvalgte. Musikdyrkelsens særpræg blev især kommunikeret til omverdenen af Christian Olsen gennem hans bøger, artikler samt nodeudgivelser. Hertil kom efter 1926 Statsradiofoniens løbende udsendelser med gammel dansemusik, hvor Jens Olsens melodier ofte blev spillet af radioens musikere.

Særpræget blev desuden markeret indirekte ved de lokale musikaktiviteter, som Torpelund-familien normalt $i k k e$ engagerede sig i, og som foregik i 
forsamlingshuse, missionshuse, kirker, folkelige foreninger og på højskoler. Familien brugte ikke sine kræfter i praktisk folkeoplysende og opdragende arbejde med musik. Derimod skabte Torpelundfamiliens private musikdyrkelse relationer til mennesker, man ønskede at omgås.

Herved illustrerer Olsen-familien en af musikvidenskabens nye erkendelser, nemlig at alle kategorier af deltagere i en musikalsk performance har en vigtig rolle. Lytterne, værterne og dem, der ytrer sig i den efterfølgende diskussion, er lige så definerende for musikkens betydning $i$ et miljø, som de udøvende musikere. Musikantropologen Christopher Small har lanceret en teori om musikkens betydning ved en performance, nemlig at "musicering handler om relationer. Ikke så meget om dem, der faktisk eksisterer i vores liv, som om dem, vi ønsker skal eksistere og længes efter at opleve”. ${ }^{4}$ Sådan har det været på Torpelund, som man kan se bekræftet i Christian Olsens dagbøger.

\section{Arven gives videre}

Folk på egnen sagde, at nye tjenestefolk på Torpelund enten hurtigt forsvandt igen eller i stedet blev der hele livet.

\section{Noter}

1 Se Jens Henrik Koudal: "Musikkens betydning på en større gård i mellemkrigstiden", Kulturstudier, 1, 2013, s. 6-33; og samme: "Fra bondedans til karakterstykke for klaver. Musik i et proprietærlignende miljø i mellemkrigstiden", Fund og Forskning, 52, 2014, s. 325-80.

2 Renskrevet notat fra 3. juni 1949, Dansk Folkemindesamling 2011/1, IVCe.
Louis Helt var en af den sidste slags. Han var fra et lille boelsmandssted på egnen. Som dreng løb han på Torpelund og tjente lidt ved forefaldende arbejde, især når der skulle tages kartofler op. Efter sin konfirmation i 1939 blev han tjenestekarl på gården, hvor han arbejdede hårdt i stalden og på markerne. Han gled efter få år helt ind i livsformen og lærte snart at spille violin. Når kredsen samledes, spillede han både klassiske violinsonater og "Ole Bulls polka". Det var også ham, der købte og betjente en båndoptager, $\mathrm{da}$ Christian Olsen $\mathrm{i}$ midten af 1950'erne ville dokumentere miljøets musicering.

Skæbnen ville, at Christian Olsen i 1968 døde som den sidste af søskendeflokken og ikke havde nogle livsarvinger. Han testamenterede derfor gården og de 120 tønder land til Louis, som drev den videre i 17 år. Det var Louis Helt, der for få år siden forærede Christian Olsens privatarkiv til Dansk Folkemindesamling. Torpelund ligger stadig, let genkendelig, i Torpe i Bregninge sogn. Under sin nuværende ejerfamilie er gården ikke længere musikalsk samlingssted, men kendt for sin gode kartoffelavl.

3 Tove Meyer Hægstad: "At redde fra glemsel" [artikel baseret på interview med Christian Olsen]. Berlingske Tidende, 2. sektion, 3. december 1961.

4 Christopher Small: Musicking. The meaning of performing and listening, Wesleyan University Press, Middletown Connecticut 1998 , s. 183. 